\title{
СОЗДАНИЕ СОРТА МЯГКОЙ ЯРОВОЙ ПШЕНИЦЫ ГРЕНАДА С ПОМОЩЬЮ ИННОВАЦИОННЫХ ТЕХНОЛОГИЙ СЕЛЕКЦИИ НА ОСНОВЕ ТЕОРИИ ЭКОЛОГО-ГЕНЕТИЧЕСКОЙ ОРГАНИЗАЦИИ КОЛИЧЕСТВЕННЫХ ПРИЗНАКОВ
}

\author{
В.В. НОВОХАТИН ${ }^{1}$, В.А. ДРАГАВЦЕВ ${ }^{2}$, Т.А. ЛЕОНОВА' 1 , Т.В. ШЕЛОМЕНЦЕВА 1
}

Существующая в настоящее время вера в перспективность молекулярных подходов к решению проблемы повышения урожаев, по нашему мнению, избыточна, так как пока нет ни одного сорта, созданного исключительно молекулярными методами. Кроме того, представители эпигенетики справедливо утверждают, что в природе не существует специфических генов продуктивности и урожая, следовательно, невозможно их молекулярное маркирование или геномное редактирование. В этом сообщении мы представляем итоги применения инновационных селекционных технологий, вытекающих из приоритетной российской теории эколого-генетической организации количественных признаков (ТЭГОКП), которая была разработана в процессе выполнения Межведомственной программы ДИАС (изучение генетики признаков продуктивности яровых пшениц в Западной Сибири, 1973-1984 годы). Суть инноваций заключается в следующем: подбор родительских пар осуществляется особым способом на основе глубокого анализа максимально протяженных родословных древ сортов-родителей, взятых в скрещивания; для группы самых урожайных сортов коллекционного питомника выполняется фенотипирование (phenotyping) по семи генетико-физиологическим системам (ГФС), открытым и описанным в процессе развития ТЭГОКП и дающим плюсовые или минусовые вклады в урожай; отбираются генотипы, имеющие хотя бы одну ГФС с максимальным плюсовым вкладом в урожай, и выполняются их скрещивания для совмещения в будущем сорте плюсовых вкладов всех семи ГФС; производятся стабилизирующие пересевы расщепляющихся поколений для устранения эффектов доминирования, сверхдоминирования и гетерозиготного эпистаза (с несколькими насыщениями геномом одного из родителей, имеющего наиболее ценные свойства); после ряда стабилизирующих пересевов гибридной популяции в условиях типичной динамики лим-факторов среды (в годы, типичные по погодным условиям для зоны селекции) отбираются элитные растения. Применив эти новые технологии (20012014 годы), мы получили гибридную комбинацию $\mathrm{F}_{1}$ (сорта Казахстанская раннеспелая $\times$ Тулунская 12) с 1-кратным последующим насыщением сортом Тулунская 12, из которой выделился сорт Гренада. При этом родители материнской формы гибрида - сорта Казахстанская раннеспелая (Новосибирская 67 × Омская 9), имеющие широкую амплитуду общей адаптивности, показали при смене лим-факторов среды гораздо менышую степень переопределения вкладов разных ГФС в продуктивность и хорошую комбинационную способность. Созданный на их основе сорт Казахстанская раннеспелая сочетает в себе лучшие проявления признаков родительских сортов. У отцовской и насыщающей формы Тулунская 12 улучшение количественных признаков носит дискретно-накопительный характер за счет генетического многообразия восточно-сибирских генотипов. Отбор элитных растений в типичных агроклиматических условиях дал генотипы более урожайные и имеющие хорошо выраженную пластичность урожаев. Комплексная оценка биотипов, отобранных из этой популяции в $\mathrm{F}_{5}$ по каждой из семи ГФС, вносящих положительный вклад в повышение продуктивности, показала эффективность выполненного нами фенотипирования, что хорошо проявилось у раннеспелой линии Лютесценс 506-11, ставшей впоследствии сортом Гренада. У сорта высокая продуктивность (превышение стандарта на 26-39 \%) удачно сочетается с устойчивостью к полеганию, засухоустойчивостью, устойчивостью к предуборочному прорастанию зерна в колосе и качеством зерна (соответствует таковому ценных и сильных сортов). Отличительная особенность созданного сорта - горизонтальная устойчивость к септориозу, пыльной головне, мучнистой росе, красногрудой пьявице, внутристеблевым вредителям. Сорт Гренада много меньше стандарта поражается ржавчинными грибами. Сбор белка у сорта Гренада составляет 628 кг/га, что на 119 кг больше, чем у стандартного сорта. С 21 февраля 2019 года сорт Гренада районирован в России по 9-му (Уральскому) растениеводческому региону, включая Башкирию (около 1 млн га), Челябинскую (1 млн га), Оренбургскую (4 млн га), Курганскую (1 млн га) и Тюменскую (500 тыс. га) области. При выращивании сорта Гренада на этих площадях прибавки урожая должны давать ежегодный экономический эффект около 30 млрд руб.

Ключевые слова: Triticum aestivum L., мягкая пшеница, селекция, сорт, популяция, отбор, биотип, генетико-физиологическая система, зерно, иммунитет.

Современное решение проблемы повышения урожаев различных

* Работа выполнена по Государственному заданию (приоритетное направление Х.10.4, программа X.10.4.150, проект Х.10.4.150). 
культур на сегодняшний день не вполне адекватно связывают с технологиями, основанными на методах культуры клеток и ткани $(1,2)$ и молекулярной генетики (3-6). Обсуждается эффективность разных молекулярных маркеров (7, 8), маркер-вспомогательной селекции (marker-assisted selection, MAS), маркер-опосредованного бэккроссирования (marker-assisted backcrossing, MABC), маркер-опосредованной рекуррентной селекции (markerassisted recurrent selection, MARS), геномной селекции (genome-wide selection, GWS, genomic selection, GS) $(9,10)$, а также геномного редактирования (11).

Принято считать, что ключевые признаки (урожай зерна, содержание в нем белка, горизонтальный иммунитет) контролируются многими генами. Такие признаки получили название количественных (КП), или сложных полигенных (12-15). КП зависит от совокупного действия набора генов и окружающей среды. Локусы количественного признака (quantitative trait loci, QTL) могут включать один ген или группу генов, вносящих вклад в величину признака, причем эффекты обычно изменяются в зависимости от условий, в которых признак проявляется (16). Используя молекулярные маркеры, можно проанализировать количественные признаки и идентифицировать вклады в признак QTL, то есть генов, контролирующих сложные признаки, которые представляют интерес в селекционных программах (17-19).

Однако, по нашему мнению, ожидания того, что ключом к решению проблемы быстрого создания сортов с требуемыми свойствами для удовлетворения растущих потребностей населения Земли будут служить исключительно молекулярные и генно-инженерные методы, избыточны. В литературе пока нет ни одного сообщения о создании какого-либо сорта только на основе молекулярных подходов. Кроме того, представители эпигенетики (20-22) справедливо утверждают, что в природе не существует специфических генов продуктивности и урожая, следовательно, невозможно их молекулярное маркирование или геномное редактирование. И поныне в генетике и селекции диаллельный анализ признаков продуктивности растений остается очень эффективным методом создания сортов с высокими и качественными урожаями (23-25), а ведь он не включает в себя молекулярных характеристик.

В 1973-1984 годах в СССР выполнялась Межведомственная кооперативная программа ДИАС (диаллельные скрещивания), в задачи которой входило изучение генетики признаков продуктивности яровой пшеницы в условиях Западной Сибири и Казахстана (26). В исследованиях участвовали специалисты восьми сибирских селекционных центров и двух научных центров - Института цитологии и генетики СО АН СССР (ИЦиГ СО АН СССР) и Вычислительного центра СО АН СССР (ВЦ СО АН СССР). Территория, на которой проводили эксперименты, - от Красноуфимска (Урал) до Иволгинска (Забайкалье) по параллели, и от Тюмени до УстьКаменогорска по меридиану. Были отобраны 15 родительских сортов (из России, США, Японии, Швеции, Канады и Индии) и скрещены по диаллельной схеме (каждый с каждым). Зимой семена поколения $\mathrm{F}_{1}$ высевали в красноярском фитотроне для получения семян $F_{2}$, а летом родительские сорта, гибридное поколение $\mathrm{F}_{1}$ и гибридное поколение $\mathrm{F}_{2}$ высевали по схеме полных случайных блоков в 4 повторностях в 8 географических точках. Опыты продолжались 2 года. На каждом растении учитывали 15 признаков продуктивности, результаты (около 5 млн измерений) помещали в банк данных программы ДИАС, созданный в ВЦ СО АН СССР, данные обрабатывали на ЭВМ ВЦ СО АН СССР по оригинальным программам, раз- 
работанным сотрудниками вычислительного центра. В $\mathrm{F}_{2}$ и последующих поколениях селекционеры во всех 8 точках вели индивидуальные отборы, далее размножали семьи и затем проводили весь цикл стандартного селекционного процесса - оценку материала в ряду селекционных питомников. Кроме сортов, созданных при выполнении программы, была открыта новая система регуляции в развитии признаков продуктивности и урожая смена набора продуктов генов, детерминирующих один и тот же признак продуктивности, при смене лимитирующего фактора среды. На основе этого открытия в 1984-2014 годах получила развитие приоритетная российская теория эколого-генетического контроля количественных признаков (ТЭГОКП, научная школа В.А. Драгавцева) (27-29). На основе теории разработаны 24 принципиально новых следствия, позволивших делать 24 прогноза параметров для любых временны́х динамик лим-факторов среды, а также предложены 10 ноу-хау с мощными возможностями более эффективной селекции на повышение урожая и его качества.

Одновременно с развитием ТЭГОКП были открыты и описаны семь генетико-физиологических систем (ГФС) (30), с помощью которых селекционеры de facto (часто не осознавая этого) повышают продуктивность и урожаи новых сортов. На основе приоритетных методов количественной идентификации плюсовых вкладов этих систем в продуктивность и урожай стандартных и новых сортов была разработана оригинальная система фенотипирования (phenotyping) каждой из семи ГФС. Она отличается от традиционных зарубежных систем фенотипирования (в них результирующий признак - урожай расчленяется последовательно на более мелкие компонентные признаки) тем, что работа ведется не с признаками, а с ГФС. Признаки при этом служат осями двумерных систем координат, в которых каждая ГФС проявляет свой положительный или отрицательный вклад в продуктивность в «очищенном» от всяких шумов генетически «оголенном» количественном значении (31). Эти ГФС следующие: ГФС аттракции, которая обеспечивает в период налива отток пластических веществ из соломы и листьев в колос (злаки) или из стебля и листьев в корзинку (подсолнечник) (АТТР); ГФС микрораспределений аттрагированных пластических веществ между зерном и мякиной у колосовых или между ядром и лузгой у подсолнечника (МИК); ГФС адаптивности (морозо-, холодо-, засухо-, жаро-, солеустойчивости, устойчивости к $\mathrm{pH}$ почвы и т.п.) (АД); ГФС полигенного иммунитета (горизонтальной устойчивости) (ИММ); ГФС толерантности к загущению фитоценоза (ТОЛ); ГФС «оплаты» сухой биомассой низких доз почвенного питания (лим-факторов почвенного питания - N, P, К) (ЭФФ); ГФС генетической вариабельности длины фаз онтогенеза (ОНТ) (31).

В этой статье на примере создания сорта яровой пшеницы Гренада впервые описаны прорывные технологии инновационного конструирования сортов с высокими урожаями и качеством продукции, превосходящих существующие сорта. Эти технологии стали практическим следствием приоритетной Теории эколого-генетической организации количественных признаков (ТЭГОКП), которая опередила развитие экологической генетики растений в мире на 10-15 лет. Они составляют альтернативу созданию генно-модифицированных растений, поискам QTLs и попыткам маркирования признаков продуктивности и не имеют аналогов в мире.

Цель работы - применить при создании нового сорта разработанные нами новые технологии селекции на повышение урожаев, основанные на теории эколого-генетического контроля количественных признаков и на открытии семи генетико-физиологических систем, определяющих гене- 
тическое улучшение основных экономически значимых свойств растений.

Методика. Эксперименты проводили в 2001-2016 годах на опытном поле НИИ сельского хозяйства Северного Зауралья (НИИСХ Северного Зауралья, филиал Тюменского НЦ СО РАН) на темно-серой почве по черному удобренному пару $\left(\mathrm{N}_{30} \mathrm{P}_{45} \mathrm{~K}_{30}\right.$ д.в./га), а также в 2013-2014 годах на Ишимской сельскохозяйственной опытной станции (Ишимская СХОС, Тюменская обл.) на обыкновенном черноземе по черному удобренному пару $\left(\mathrm{N}_{30} \mathrm{P}_{30}\right.$ кг д.в./га). В коллекционном и селекционном питомниках использовали порционную сеялку СКС-6-10 (Россия) согласно селекционной схеме с нормой высева всхожих зерен 650 шт/м ${ }^{2}$. Гибридизацию осуществляли твел-методом (twirl method, метод Борлауга, способ опыления, при котором цветущий отцовский колос вращают внутри индивидуального изолятора с находящимся в нем кастрированным материнским колосом). Родителей и гибриды $\mathrm{F}_{1}$ и $\mathrm{F}_{2}$ высевали вручную на делянках $1 \mathrm{~m}^{2}$ с нормой высева 20 зерен на 1 м (погонный). Гибридный материал $\mathrm{F}_{3}-\mathrm{F}_{5}$ (стабилизирующие посевы) без отборов высевали на делянках площадью

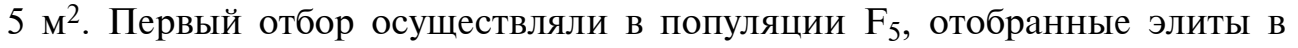
селекционном питомнике первого года (СП-1) высевали вручную в лунки $(\mathrm{d}=25 \mathrm{~cm})$. Уход и наблюдения за гибридным и селекционными питомниками проводили общепринятыми методами. Все посевы обрабатывали 1-кратно гербицидами Пума Супер 7,5, эмульсия масляно-водная (Puma Super ${ }^{\circledR}$, «Bayer CropScience AG», Германия; 0,8 л/га) + Гранстар Про, водно-диспергируемые гранулы (Granstar ${ }^{\circledR}$ Pro, «DuPont», США; 0,015 кг/га). В гибридном питомнике (родители, $\mathrm{F}_{1}, \mathrm{~F}_{2}$ ) уборку проводили вручную. Гибридологический анализ выполняли по всем признакам продуктивности и морфологическим показателям. В конкурсном сортоиспытании для пробных снопов проводили сноповой и структурный анализ (по 25 растениям в 4-кратной повторности).

Для количественного анализа вкладов каждой из семи ГФС в продуктивность осуществляли фенотипирование в двумерных системах координат разных признаков продуктивности по собственной разработанной технологии, вытекающей из ТЭГОКП $(26,30)$.

Результаты. При выполнении программы ДИАС (26) были выведены и районированы следующие сорта: ДИАС 2 - районирован в Омской и Новосибирской областях (автор Р.А. Цильке); Лютесценс $70-$ до последнего времени был главным сортом Зауралья, занимавшим более $60 \%$ посевов пшеницы (автор В.В. Новохатин); Алтайская 88 - до настоящего времени возделывается на Алтае, дает зерно высокого качества (автор Н.И. Коробейников); Алтайская 92 - среднеранний сорт, распространен в Западной Сибири (автор Н.И. Коробейников); Алтайский простор - сорт сильной пшеницы, широко распространен на Алтае (автор Н.И. Коробейников); Казахстанская раннеспелая - один из основных сортов на севере Казахстана, дает сильное по качеству зерно (автор В.В. Новохатин); Казахстанская 17 - сильный сорт, возделывается в Южном Казахстане (автор В.В. Новохатин); Рикс, внучатый сорт (Казахстанская $17 \times$ Карабалыкская 92) с урожайностью в Северном Зауралье (по удобренному пару) до 64 ц/га (автор В.В. Новохатин); Багамская 93 - сорт распространен в Барабинских степях Западной Сибири, выделяется засухо- и холодостойкостью (автор В.П. Максименко); Кантегирская 89 - районирован в Хакасии, Тыве и Монголии (авторы И.Ф. Деморенко, Р.А. Цильке); Горноуральская - внучатый сорт, районирован в 2009 году на среднем Урале (автор В.А. Воробьев); Тюменская 29 - внучатый сорт, районирован в 2014 году в 10-м регионе России (автор В.В. Новохатин); Гренада - внуча- 
тый сорт, районирован в 2019 году по 9-му (Уральскому) региону (авторы В.В. Новохатин, В.А. Драгавцев; при площадях под яровой пшеницей в этом регионе более 7 млн га ожидаемый ежегодный эффект от прибавок урожая сорта Гренада составит около 30 млрд руб.); Атланта 1 - внучатый сорт, находится в Государственном сортоиспытании с 2018 года (авторы В.В. Новохатин, В.А. Драгавцев).

Традиционная генетика со времени переоткрытия законов Г. Менделя (1900 год) призывает изучать генетику количественного признака. Однако ТЭГОКП показала, что для признака, подверженного феномену взаимодействия генотип-среда, невозможно дать стабильную «паспортную» генетическую характеристику для всех сред (27-29, 32). Это значит, что количественные признаки детерминируются «блуждающими» спектрами (наборами) продуктов генов, которые для одного и того же признака меняются при смене лим-факторов внешней среды, что ведет к сильным скачкам генотипической дисперсии (в течение суток, недель, месяцев, лет). Например, нами показано, что смена наборов продуктов экспрессии генов, которые детерминируют количественный признак «интенсивность транспирации», происходит дважды в течение суток (33).

При теоретическом обосновании создания сорта Гренада мы исходили из того, что анализ максимально протяженных родословных древ сортов позволяет в качественной форме обосновывать подбор пар для скрещиваний $(34,35)$ и вести направленный формообразовательный процесс при отборах в нужном направлении (36). В родословной сорта Гренада присутствуют 69 сортов различного генетического и эколого-географического происхождения (рис.). Но наш анализ родословных не был традиционным. Нас интересовали не просто родители каждого предка, а динамики лимитирующих факторов среды в той географической точке, где был создан соответствующий родитель. Такой подход позволял приближенно определить, какие ГФС адаптивности и для какого из 12 этапов онтогенеза растения имеются у этого родителя. Кроме того, выяснилось, что эффективность скрещиваний повышается, когда в качестве родителей селекционеры использовали сорта и формы, близкие по морфологии, но генетически разнокачественные.

Особенно четко это проявилось для озимой ветви, давшей знаменитый высокоурожайный высококачественный сорт Безостая 1 (автор П.П. Лукьяненко) - материнскую форму яровой интенсивной высококачественной среднепоздней пшеницы Омская 9. От скрещивания последней с сильным пластичным сортом Новосибирская 67, у которого улучшение количественных признаков продуктивности обусловлено мутациями при дискретном $\gamma$-облучении (5000 ренген), был создан пластичный раннеспелый сильный сорт Казахстанская раннеспелая. Генетику количественных признаков его родителей - сортов Новосибирская 67 (ㅇ) и Омская 9 (§) изучали в рамках программы ДИАС (26). Оказалось, что у них хорошо выражена комбинационная способность (26). На основании этого гибридной комбинации Новосибирская $67 \times$ Омская 9 было уделено повышенное внимание. После многократного стабилизирующего пересева этой популяции из ее пятого поколения отобрали и размножили элитное растение (образец Лютесценс 1227-8-79), ставшее родоначальником сильного сорта Казахстанская раннеспелая, который более 20 лет широко возделывается в Северном Казахстане на площади от 450 тыс. га до 1,2 млн га. Раннеспелость этого сорта обусловлена объединением продуктов генов $V r n-1$ и $V r n-3$, контролирующих ускоренное прохождение этапов органогенеза второй половины вегетации $(37,38)$. Казахстанская раннеспелая, как 


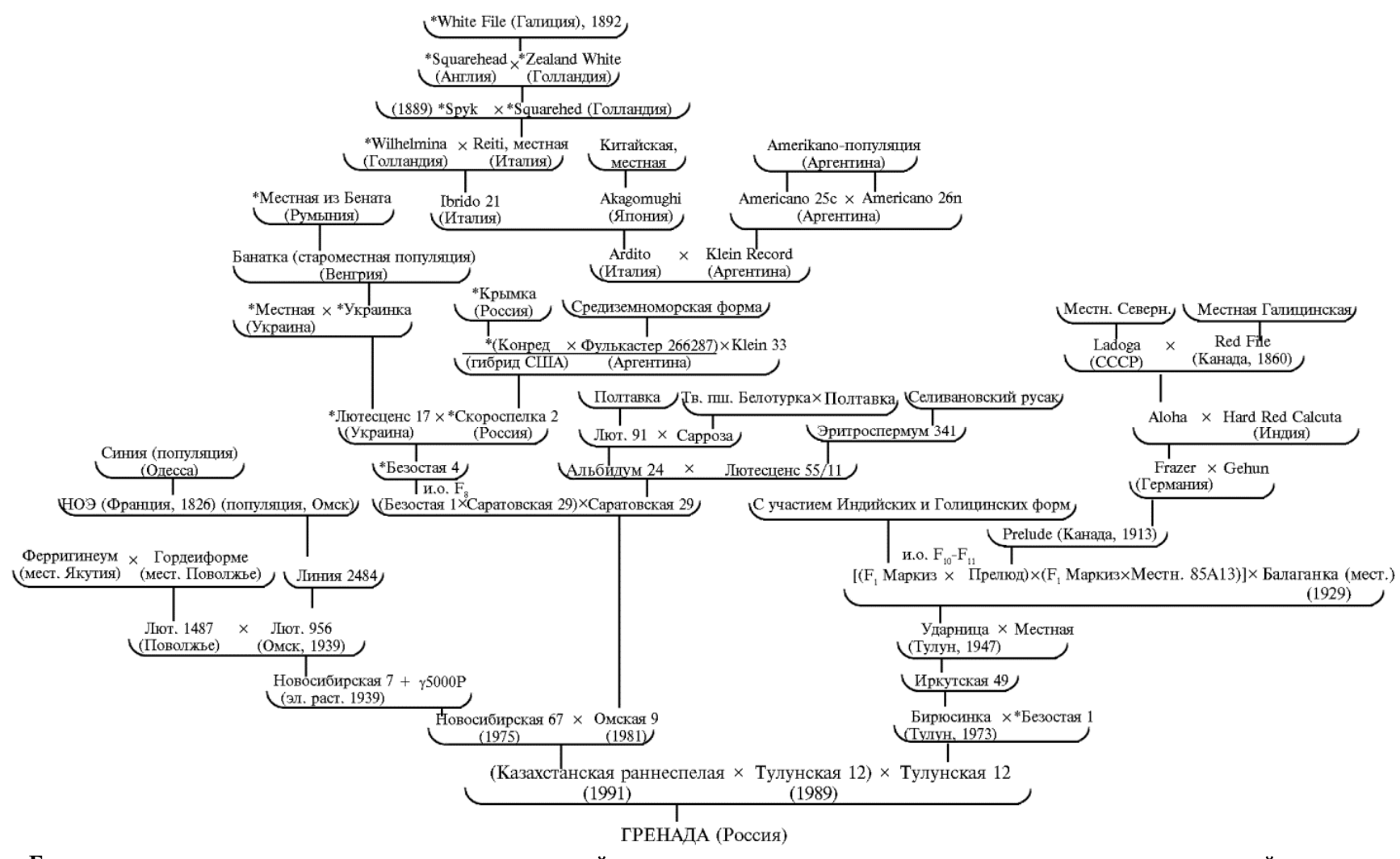

Родословная сорта Гренада, созданного с использованием инновационной технологии селекции на основе теории эколого-генетической организации количественных признаков. Звездочками отмечены озимые сорта. 
и ее родители, относится к Западно-Сибирскому экотипу. Именно она стала материнской формой нового сорта Гренада. В качестве отцовского и насыщающего $\left(\mathrm{B}_{1}\right)$ родителя использовали раннеспелый сильный сорт Тулунская 12 (Восточно-Сибирский экотип), улучшение количественных признаков которого носит дискретно-накопительный характер за счет использования канадских сортов, объединивших в себе старорусские (галицийские) и индийские формы, и местных Восточно-Сибирских генотипов, ведущих свое происхождение с XVI в. из Внутренней Монголии и Горного Китая $(39,40)$. Отличительные особенности сортов Восточно-Сибирского экотипа - ускоренный тип развития, общая засухоустойчивость и способность формировать высококачественное зерно в прохладных условиях. У этих сортов зерновки удлиненной формы и небольшая масса 1000 зерен (от 32 г) (40), что характерно и для сорта Тулунская 12. Оба родителя сорта Гренада выделяются сильным опушением листьев, имеющих темную окраску и выраженный восковой налет.

После гибридизации отбор из ранних поколений нерезультативен, потому что фенотипы растений в $\mathrm{F}_{2}$ не коррелируют с урожайностью в потомстве. Фенотипическое проявление индивидуальной продуктивности в $\mathrm{F}_{2}-\mathrm{F}_{3}$ может быть связано с эффектами доминирования, гетерозиготного эпистаза (41) и осложняться экспрессией гетерозиготных локусов сверхдоминированием (по значительному числу признаков), которое исчезает через три-четыре поколения пересевов. Последовательное снижение неаддитивной вариансы к поздним поколениям облегчает отбор в них продуктивных генотипов $(42,43)$, так как при пересеве популяции (с $\mathrm{F}_{2}$ и далее) на нее оказывает давление естественный отбор (эволюционная селекция), элиминирующий слабоадаптивные формы, сохраняя при этом более приспособленные к местным условиям и урожайные генотипы, у которых обычно проявляется хорошо выраженный синергизм с конкретными типичными для зоны селекции динамиками лим-факторов среды (36).

Созданную гибридную популяцию $\left[\mathrm{F}_{1}\right.$ (Казахстанская раннеспелая $\times$ Тулунская 12) с 1-кратным насыщением генами сорта Тулунская 12] размножали со стабилизирующими пересевами до $\mathrm{F}_{5}$ в типичных условиях северной лесостепной зоны Северного Зауралья на темно-серых почвах по удобренному $\left(\mathrm{N}_{30} \mathrm{P}_{45} \mathrm{~K}_{30}\right)$ пару. В таких условиях отбираются продуктивные формы с генетически умеренным развитием колоса, хорошим наливом и формированием выполненного зерна, что, как поясняет В.А. Кумаков (44), происходит за счет иной, чем в засушливых условиях, работы генетических систем распределения ассимилятов (систем АТТР и МИК) и ростовых функций у растений пшеницы. Потенциальную продуктивность и устойчивость к засухе контролируют различные ГФС, поэтому они могут быть улучшены отбором независимо одна от другой (45). Следовательно, в одном генотипе вполне могут сочетаться эти сложные и на первый взгляд противоречивые свойства (46).

При количественном анализе вкладов каждой ГФС в продуктивность выполнялось фенотипирование в двумерных системах координат. Например, в системе с абсциссой «масса соломины главного колоса» и ординатой «масса колоса» вдоль положительной линии регрессии будут распределяться точки генотипов с плюс- и минус-модификациями (в частности, генотип, попавший на сухой бугорок почвы, сместится влево и вниз, в углубление с водой и азотом - вправо и вверх) и с разной адаптивностью (точки более адаптивных генотипов уйдут вправо и вверх, менее адаптивных - влево и вниз). Генотипы с хорошими ГФС аттракции станут перемешаться вдоль отрицательной линии регрессии (чем выше 
аттракция, тем легче соломина и тяжелее колос), в результате генотипы с лучшими ГФС аттракции соберутся в левой верхней зоне графика. При этом отклонения по аттракции не будут замаскированы шумами экологической вариабельности микрониш под каждым генотипом и вариабельностью адаптивности генотипов (эффекты этих шумов проявятся расположением по положительной линии регрессии), так что плюсовые и минусовые генетические сдвиги по аттракции окажутся свободными от любых шумов, и их значения будут генетически чистыми (оголенными по А.C. Ceребровскому). Использование в селекционной работе (при фенотипировании) измеряемых количественных оценок для семи ГФС (30), каждая из которых вносит свой плюсовой вклад в результирующий признак (продуктивность), позволило объективно определить величины плюсовых вкладов разных ГФС в повышение урожая, выделить из популяции $\mathrm{F}_{5}$ Линию 506-11, ставшую впоследствии сортом мягкой яровой пшеницы Гренада, и охарактеризовать этот сорт.

Морфологические особенности сорта Гренада: куст полупрямостоячий, колос цилиндрический, слабо поникающий, белый, с восковым налетом, со средней плотностью (20,8 колоска на 10 см колосового стержня), имеет асимметричные остевидные отростки в верхней части. Стебель средней длины (78-88 см), устойчивый к полеганию, с сильным восковым налетом, укороченными нижними междоузлиями (первое - 4,1-4,9 см, второе - 8-9 см) диаметром соответственно 2,2-2,5 мм и 2,7-2,9 мм; листья темно-зеленые, укороченные, широкие, грубые, опушенные, с восковым налетом, не поникающие; зерновка крупная, яйцевидная, темно-красная, с неглубокой бороздкой и коротким хохолком.

Гренада - сорт раннеспелого типа (он на 3 сут более скороспелый, чем стандарт Новосибирская 31). При формировании зерна почти до полной спелости происходит постепенное усыхание вегетативной массы, обеспечивающее лучшую реутилизацию (функция ГФС АТТР - аттракция пластических веществ из стебля и листьев в колос). Благодаря этому зерновки хорошо озерненного колоса как в верхней, так и в нижней части полновесные и хорошо выполненные. Сорт формирует крупное зерно с абсолютной массой 39,7 г (+7,7 г к стандарту) и высокой натурой - 798 г/л (+35 г/л к стандарту). Технологические показатели зерна и оценка хлеба на уровне сильных и ценных сортов. Продукция белка с 1 га пашни 628 кг, что на 119 кг больше, чем у стандарта (Новосибирская 31). При этом даже в провокационных условиях полученный сорт устойчив к предуборочному прорастанию зерна в колосе.

У нового сорта хорошо выражена функция ГФС микрораспределений аттрагированных пластических веществ между зерном и мякиной в колосе. Это подтверждается соотношением массы мякины колоса к его общей массе. У родительских сортов Казахстанская раннеспелая и Тулунская 12 он составляет соответственно 23 и $19 \%$, у сравниваемых стандартов сортов Новосибирская $31-27 \%$, Ирень - $30 \%$, а у нового сорта Гренада - $20 \%$, что убедительно доказывает эффективность ГФС МИК у полученного сорта. ГФС адаптивности (АД) обеспечивают общую адаптивность к конкретному сочетанию разных лим-факторов в зоне селекции. Их набор для признака меняется в зависимости от смены лим-факторов. Эта смена приводит к феномену смены рангов продуктивности в наборе сортов от года к году, то есть к явлению «взаимодействие генотип-среда» (ВГС) $(25,47)$. В условиях Северного Зауралья из $100 \%$ фенотипической дисперсии урожаев на генотипическую приходится $25 \%$, а в генотипической дисперсии $80 \%$ обусловлено ВГС, и только $20 \%$ - аддитивными 
При этом известно (48), что если для компонентных признаков продуктивности часто преобладают аддитивные эффекты вкладов генов, то по результирующему признаку продуктивности (масса зерен с растения), как правило, преобладают неаддитивные эффекты. Поэтому управление ВГС служит основным резервом повышения урожайности $(33,49)$. Недавно природа явления ВГС была полностью расшифрована (47). Функционирование ГФС АД у сорта Гренада выражается выносливостью при раннелетней засухе (благодаря хорошо развитой корневой системе) и хорошей общей засухоустойчивостью, обеспеченной плотным кутикулярным восковым налетом (50), а также способностью хорошо развиваться на слабокислых почвах и формировать качественное, натурное зерно в прохладные месяцы. Это подтвердили как 4-летние конкурсные, так и Государственные сортоиспытания сорта Гренада в контрастных агроклиматических условиях на обширной территории 9-го (Уральского) растениеводческого региона.

ГФС полигенного иммунитета (горизонтальной устойчивости) у нового сорта обусловлена сильным кутикулярным восковым налетом на листьях и стеблях, что препятствует прорастанию спор патогенных грибов. В провокационных условиях (искусственный фон заражения) сорт Гренада проявляет высокую горизонтальную устойчивость к септориозу, пыльной головне, мучнистой росе; он значительно меныше стандарта поражается ржавчинными грибами, толерантен к красногрудой пьявице. Наличие густого опушения листьев и стебля также предохраняет растения сорта Гренада от внутристеблевых вредителей (табл.).

Интенсивное ведение селекции сопровождается микроэволюционными процессами (51-54) за счет рекомбиногенеза (55), влияния абиотических факторов $(56,57)$, инфекционных фонов $(58,59)$, естественного и искусственного отборов $(46,60)$, что позволяет создавать продуктивные, адаптированные к местным условиям генотипы с выраженным синергизмом их биотипов и среды $(61,62)$. Это благоприятствует отбору форм с наличием ГФС толерантности к загущению (ТОЛ), что хорошо проявилось у сорта Гренада. В Северном Зауралье из-за ограниченного периода вегетации урожай пшеницы формируется в основном за счет главных стеблей (62). При норме высева 6,5 млн всхожих зерен на 1 га с полевой всхожестью в пределах 70 \% при сохранности растений $93 \%$ и продуктивной кустистости 1,22 (почти так называемая однобылка) у растений сорта Гренада, по среднемноголетним данным, формируется примерно 517 продуктивных стеблей на 1 м². При продуктивности колоса 1,1-1,2 г (28-30 зерен с массой одного зерна 0,04 г) биологическая урожайность нового сорта составляет 5,7-6,2 т/га.

ГФС «оплаты» сухой биомассой низких доз почвенного питания (лим-факторов $\mathrm{N}, \mathrm{P}, \mathrm{K}$ ) во многом определяет эффективность сорта при низких дозах азота, фосфора, калия. Довольно объективным показателем функций ГФС АТТР и ЭФФ служит коэффициент хозяйственной годности (отношение массы зерна на делянке к общей сухой биомасcе, harvest index). У стандарта и сравниваемых сортов он составляет 0,30-0,34, а у сорта Гренада - 0,42 (то есть доля зерна в общей сухой биомассе растений $-42 \%)$. Этот показатель позволяет сорту формировать на темно-серых почвах (при невысоких дозах минеральных удобрений - $\mathrm{N}_{30} \mathrm{P}_{45} \mathrm{~K}_{30}$ ) растения средней высоты (до 88 см) с ограниченной кустистостью (коэффициент кущения 1,22), продуктивно работающим ассимиляционным аппаратом (благодаря укороченным, широким, толстым, грубым, не поникающим листьям, которые не поражаются патогенами, что свойственно и стеблю). Рас- 
тения долго вегетируют, эффективно используют фотосинтетически активную радиацию (ФАР), при этом имеют хорошо развитую и активно работающую корневую систему.

В совокупности изменения в ГФС, которые были достигнуты в результате гибридизации и селекции, обеспечили у созданного сорта достоверное повышение урожайности зерна в полевых условиях. Так, в конкурсном сортоиспытании (НИИСХ Северного Зауралья) при высокой естественной патогенной нагрузке на темно-серой почве (удобренный пар, $\left.\mathrm{N}_{30} \mathrm{P}_{45} \mathrm{~K}_{30}\right)$ у сорта Гренада в среднем за 4 года (2013-2016 года) урожайность составила 4,24 т/га, что на 0,87 т/га (+26 \%) достоверно превысило показатель у стандарта (сорт Новосибирская 31) $\left(\mathrm{HCP}_{05}=0,24\right.$ т/га) (см. табл.). Аналогичное превышение, но при меньшей урожайности $(3,31$ т/га, +39 \% к стандарту) наблюдали на неудобренной зяби. Рост урожайности относительно стандарта $(+0,47$ т/га, или $+17 \%)$ также отмечали в экологическом сортоиспытании на Ишимской СХОС на юге Тюменской области в 2013-2014 годах.

Хозяйственные и биологические характеристики сорта мягкой яровой пшеницы Гренада в сравнении со стандартом

\begin{tabular}{|c|c|c|c|c|c|}
\hline \multirow{2}{*}{ Показатель } & \multirow{2}{*}{$\begin{array}{l}\text { Единица } \\
\text { измерения }\end{array}$} & \multirow[t]{2}{*}{ Гренада } & \multirow{2}{*}{$\begin{array}{l}\text { Новосибирская } \\
31 \text { (стандарт) }\end{array}$} & \multicolumn{2}{|c|}{$\begin{array}{l}\text { Отклонение } \\
\text { от стандарта }\end{array}$} \\
\hline & & & & $+/-$ & $\%$ \\
\hline \multicolumn{6}{|c|}{ У ро жа й н ость } \\
\hline \multirow{2}{*}{\multicolumn{6}{|c|}{$\begin{array}{l}\text { НИИСХ Северного Зауралья } \\
\text { (Тюменская обл., 2013-2016 годы): }\end{array}$}} \\
\hline & & & & & \\
\hline пар & т/га & 4,24 & 3,37 & $+0,87$ & +26 \\
\hline $\mathrm{HCP}_{05}$ & т/га & 0,24 & & & \\
\hline зябь & т/га & 3,31 & 2,38 & $+0,93$ & +39 \\
\hline $\mathrm{HCP}_{05}$ & т/га & 0,26 & & & \\
\hline \multicolumn{6}{|l|}{ Ишимская СХОС, } \\
\hline (Тюменской обл., 2013-2014 годы) & т/га & 4,53 & 4,06 & $+0,47$ & +17 \\
\hline $\mathrm{HCP}_{05}$ & т/га & 0,18 & & & \\
\hline \multicolumn{6}{|c|}{$\begin{array}{c}\text { Б и о л о г и ч е с к и е и т е х н о л о г и ч е с к и е п о к а з а т е л и } \\
\text { (НИИСХ Северного Зауралья, Тюменская обл., 2013-2016 годы) }\end{array}$} \\
\hline Период вегетации & сут & 82 & 85 & -3 & \\
\hline Высота растений & $\mathrm{cm}$ & 76 & 82 & -6 & \\
\hline \multicolumn{6}{|l|}{ Устойчивость: } \\
\hline к полеганию & балл & 5 & 4 & +1 & \\
\hline К засухе & балл & 5 & 5 & 0 & \\
\hline к пониканию & балл & 1 & 1 & 0 & \\
\hline \multicolumn{6}{|l|}{ Прорастание зерна в колосе } \\
\hline (провокационные условия) & $\%$ & 1,03 & 13,40 & $-12,37$ & \\
\hline Масса 1000 зерен & $\Gamma$ & 39,7 & 32,0 & $+7,7$ & \\
\hline Натура зерна & г/л & 798 & 763 & +35 & \\
\hline Стекловидность & $\%$ & 59 & 62 & -3 & \\
\hline \multicolumn{6}{|l|}{ Содержание: } \\
\hline протеина & $\%$ & 14,8 & 15,1 & $-0,3$ & \\
\hline клейковины & $\%$ & 33,1 & 33,8 & $-0,7$ & \\
\hline Сила муки & e.a. & 386 & 311 & +75 & \\
\hline $\mathrm{P} / \mathrm{L}$ & & 1,3 & 0,9 & $+0,4$ & \\
\hline Валориметрическая оценка & e.a. & 52 & 70 & -18 & \\
\hline Разжижение & e.ф. & 64 & 69 & -5 & \\
\hline ИДК & ед. ИДК & 80 & 78 & +2 & \\
\hline Объем хлеба (без добавок) & мл & 720 & 697 & +23 & \\
\hline Оценка хлеба & балл & 4,5 & 4,0 & $+0,5$ & \\
\hline \multicolumn{6}{|c|}{$\begin{array}{c}\text { По р а же н и е п а т о ге н а м и } \\
\text { (НИИСХ Северного Зауралья, Тюменская обл., 2014-2016 годы) }\end{array}$} \\
\hline Puccinia recondita Dietel \& Holw., 1857 & & & & & \\
\hline $\begin{array}{l}\text { (бурая ржавчина, искусственный фон) } \\
\text { Ustilago tritici (Pers.) C.N. Jensen, Kellerm. }\end{array}$ & тип/\% & $1 / 10-2 / 20$ & $2 / 20-3 / 60$ & & \\
\hline $\begin{array}{l}\text { \& Swingle (пыльная головня, искусствен- } \\
\text { ный фон) }\end{array}$ & $\%$ & $0,1-0,2$ & $2,3-4,2$ & & \\
\hline $\begin{array}{l}\text { Septoria tritici (септориоз, высокая } \\
\text { естественная нагрузка) }\end{array}$ & тип/\% & следы-1/5 & $2 / 20-3 / 60$ & & \\
\hline $\begin{array}{l}\text { П р и м е ч а н и е. P/L - отношение упр } \\
\text { единицах измерителя деформации клей } \\
\text { веографа. }\end{array}$ & $\begin{array}{l}\text { ругости к рас } \\
\text { йовины); е.ф }\end{array}$ & $\begin{array}{l}\text { кению тест } \\
- \text { единиць }\end{array}$ & $\begin{array}{l}\text { ед. ИДК - качеств } \\
\text { фаринографа, е.а. }\end{array}$ & $\begin{array}{l}\text { о клейк } \\
- \text { един }\end{array}$ & ины ( \\
\hline
\end{tabular}


Фазы онтогенеза у растений сорта Гренада в большинстве лет соответствовали типичной динамике лим-факторов для зоны Тюменской области. Поэтому при создании этого сорта не потребовались меняющие их продолжительность селекционные сдвиги (ГФС ОНТ), хотя генетические возможности для существенных изменений этого признака имеются (сорта с соответствующим генотипом известны) (63).

Полученный сорт рекомендуется для подтаежной, северной и южной лесостепных зон Сибири, Зауралья и Предуралья.

Таким образом, научным итогом крупнейшей генетико-селекционной программы ДИАС стала разработка ТЭГОКП с ее 24 следствиями и 10 ноу-хау (7). Нами впервые реализован приоритетный авторский комплекс инновационных технологий селекции, основанный на ТЭГОКП и открытых в процессе ее развития семи генетико-физиологических системах (ГФС) растений, обусловливающих в итоге урожаи любых сортов. Создание исходного селекционного материала по новым технологиям включает подбор родительских пар на основе систем ГФС, скрещивание, стабилизирующие пересевы, отбор и проводится по шестиэтапному алгоритму, предложенному и испытанному впервые. Последовательность этапов: 1-й - особый подбор родительских пар на основе глубокого анализа максимально протяженного родословного древа сортов-родителей, взятых в скрещивание, с учетом типичных динамик лим-факторов в зонах создания этих сортов-родителей; 2-й - фенотипирование по семи ГФС, дающих вклады в урожайность, в группе наиболее продуктивных сортов селекционного питомника (выполняется по приоритетной авторской методике); 3-й отбор генотипов, имеющих хотя бы одну ГФС с максимальным плюсовым вкладом в урожайность; 4-й - скрещивания этих генотипов для совмещения в одном будущем сорте плюсовых вкладов всех семи ГФС; 5-й - стабилизирующие пересевы расщепляющихся поколений для устранения эффектов доминирования, сверхдоминирования и гетерозиготного эпистаза (с несколькими насыщениями из генома одного из родителей, несущего наиболее ценные характеристики); 6-й - отбор элитных растений после ряда стабилизирующих пересевов популяции на фоне типичных динамик лим-факторов среды (в типичные годы) для зоны селекции.

Итак, использование предложенного нами блока инновационных технологий селекции, включающего шесть этапов, позволяет создавать сорта с превышением стандартов по урожаю до $40 \%$ и более, что при сортосменах гарантирует существенные прибавки к валовым сборам зерна в конкретных зонах селекции. Особенно важна оценка отбираемых генотипов по функциональной активности семи генетико-физиологическим систем (ГФС), то есть по их плюсовым вкладам в урожайность в течение всего стандартного селекционного процесса (от коллекционного питомника через питомники гибридизации, отборов, испытания семей, через предварительные, экологические и конкурсные испытания до передачи сорта в Государственную сортоиспытательную сеть). Это дает возможность, объединив в одном будущем сорте максимальные вклады всех семи ГФС, создавать высокоурожайные, устойчивые к полеганию и патогенам, формирующие высокое качество зерна, адаптивные и пластичные сорта мягкой яровой пшеницы. Применение инновационных технологий селекции, основанных на прогнозе плюсовых вкладов ГФС в урожайность, позволило объективно оценить полученный селекционный материал и выделить из него раннеспелую, урожайную, интенсивную, пластичную линию - Лютесценс 506-11, ставшую сортом Гренада. Использование разработанных нами инновационных технологий селекции резко снижает объем селекци- 


\section{Л ИТ Е РАТ УРА}

1. Loyola-Vargas V.M., Ochoa-Alejo N. An introduction to plant tissue culture: advances and perspectives. In: Plant cell culture protocols. Methods in molecular biology, Vol. 1815 /V. LoyolaVargas, N. Ochoa-Alejo (eds.). Humana Press, New York, NY, 2018: 3-13 (doi: 10.1007/978-14939-8594-4_1).

2. Bridgen M.P., Van Houtven W., Eeckhaut T. Plant tissue culture techniques for breeding. In: Ornamental crops. Handbook of plant breeding, Vol. 11 /J. Van Huylenbroeck (ed). Springer, Cham, 2018: 127-144 (doi: 10.1007/978-3-319-90698-0_6).

3. Varshney R.K., Pandey M.K., Chitikineni A. Plant genetics and molecular biology: an introduction. In: Plant genetics and molecular biology. Advances in biochemical engineering/biotechnology, Vol. 164 /R. Varshney, M. Pandey, A. Chitikineni (eds.). Springer, Cham, 2018: 1-9 (doi: 10.1007/10_2017_45).

4. Pérez-de-Castro A.M., Vilanova S., Cacizares J., Pascual L., Blanca J.M., Díez M.J., Prohens J., Picy B. Application of genomic tools in plant breeding. Curr. Genomics, 2012, 13(3): 179-195 (doi: 10.2174/138920212800543084).

5. Ashkani S., Rafii M.Y., Shabanimofrad M., Miah G., Sahebi M., Azizi P., Tanweer F.A., Akhtar M.S., Nasehi A. Molecular breeding strategy and challenges towards improvement of blast disease resistance in rice crop. Front. Plant Sci., 2015, 6: Article 886 (doi: 10.3389/fpls.2015.00886).

6. Prohens J. Plant breeding: a success story to be continued thanks to the advances in genomics. Front. Plant Sci., 2011, 2: Article 51 (doi: 10.3389/fpls.2011.00051).

7. Mammadov J., Aggarwal R., Buyyarapu R., Kumpatla S. SNP markers and their impact on plant breeding. Int. J. Plant Genomics, 2012, 2012: 728398 (doi: 10.1155/2012/728398).

8. Kim S.K., Nair R.M., Lee J., Lee S.-H. Genomic resources in mungbean for future breeding programs. Front. Plant Sci., 2015, 6: Article 626 (doi: 10.3389/fpls.2015.00626).

9. Jiang G.-L. Molecular markers and marker-assisted breeding in plants. In: Plant breeding from laboratories to fields /S.B. Andersen (ed.). IntechOpen, 2013: 45-83 (doi: 10.5772/52583).

10. Bhat J.A., Ali S., Salgotra R.K., Mir Z.A., Dutta S., Jadon V., Tyagi A., Mushtaq M., Jain N., Singh P.K., Singh G.P., Prabhu K.V. Genomic selection in the era of next generation sequencing for complex traits in plant breeding. Front. Genet., 2016, 7: 221 (doi: 10.3389/fgene.2016.00221).

11. Nadeem M.A., Nawaz M.A., Shahid M.Q., Doğan Y., Comertpay G., Yıldız M., Hatipoğlu R., Ahmad F., Alsaleh A., Labhane N., Özkan H., Chung G., Baloch F.S. DNA molecular markers in plant breeding: current status and recent advancements in genomic selection and genome editing. Biotechnology \& Biotechnological Equipment, 2018, 32(2): 261-285 (doi: 10.1080/13102818.2017.1400401).

12. Kumari S., Jaiswal V., Mishra V.K., Paliwal R., Balyan H.S., Gupta P.K. QTL mapping for some grain traits in bread wheat (Triticum aestivum L.). Physiol. Mol. Biol. Plants, 2018, 24(5): 909-920 (doi: 10.1007/s12298-018-0552-1).

13. Lozada D.N., Mason R.E., Sukumaran S., Dreisigacker S. Validation of grain yield QTLs from soft winter wheat using a CIMMYT spring wheat panel. Crop Sci., 2018, 58: 1964-1971 (doi: 10.2135/cropsci2018.04.0232).

14. Nedelkou I.-P., Maurer A., Schubert A., Léon J., Pillen K. Exotic QTL improve grain quality in the tri-parental wheat population SW84. PLoS ONE, 2017, 12(7): e0179851 (doi: 10.1371/journal.pone.0179851).

15. Guo Y., Du Z., Chen J., Zhang Z. QTL mapping of wheat plant architectural characteristics and their genetic relationship with seven QTLs conferring resistance to sheath blight. PLoS ONE, 2017, 12(4): e0174939 (doi: 10.1371/journal.pone.0174939).

16. Gahlaut V., Jaiswal V., Tyagi B.S., Singh G., Sareen S., Balyan H.S., Gupta P.K. QTL mapping for nine drought-responsive agronomic traits in bread wheat under irrigated and rain-fed environments. PLoS ONE, 2017, 12(8): e0182857 (doi: 10.1371/journal.pone.0182857).

17. Imai A., Yoshioka T., Hayashi T. Quantitative trait locus (QTL) analysis of fruit-quality traits for mandarin breeding in Japan. Tree Genetics \& Genomes, 2017, 13: 79 (doi: 10.1007/s11295017-1162-8).

18. Hernández Mora J.R., Micheletti D., Bink M., Van de Weg E., Cantín C., Nazzicari N., Caprera A., Dettori M.T., Micali S., Banchi E., Campoy J.A., Dirlewanger E., Lambert P., Pascal T., Troggio M., Bassi D., Rossini L., Verde I., Quilot-Turion B., Laurens F., Arús P., Aranzana M.J. Integrated QTL detection for key breeding traits in multiple peach progenies. BMC Genomics, 2017, 18: 404 (doi: 10.1186/s12864-017-3783-6).

19. Tan Z., Zhang Z., Sun X., Li Q., Sun Y., Yang P., Wang W., Liu X., Chen C., Liu D., Teng Z., Guo K., Zhang J., Liu D., Zhang Z. Genetic map construction and fiber quality QTL 
mapping using the CottonSNP80K array in upland cotton. Front. Plant Sci., 2018, 9: Article 225 (doi: 10.3389/fpls.2018.00225).

20. Weinhold B. Epigenetics: the science of change. Environ. Health Perspect., 2006, 114(3): A160A167 (doi: 10.1289/ehp.114-a160).

21. Chen M., Lv S., Meng Y. Epigenetic performers in plants. Develop. Growth Differ., 2010, 52: 555-566 (doi: 10.1111/j.1440-169X.2010.01192.x).

22. Gallusci P., Dai Z., Génard M., Gauffretau A., Leblanc-Fournier N., Richard-Molard C., Vile D., Brunel-Muguet S. Epigenetics for plant improvement: current knowledge and modeling avenues. Trends in Plant Science, 2017, 22(7): P610-623 (doi: 10.1016/j.tplants.2017.04.009).

23. Milomrica R.M., Dragan S.D., Desimir S.K., Fleksandar S.P., Snezana T.T. Combining abilities for spike traits in diallel cross of barley. J. Central Eur. Agric., 2014, 15(1): 198-116 (doi: 10.5513/JCEA01/15.1.1419).

24. Sing B., Sharma A., Joshi N., Mittal P., Singh S. Combining ability analysis for grain yield and its components in malt barley (Hordeum vulgare L.). Indian Journal of Agricultural Sciences, 2013, 83(1): 96-98.

25. Компанец Е.В., Козаченко М.Р., Васько А.Г., Наумов А.Г., Солонечный П.Н., Святченко С.И. Комбинационная способность сортов ячменя ярового в системе прямых диаллельных скрещиваний. Вавиловский журнал генетики и селекции, 2017, 21(5): 537-544 (doi: 10.18699/VJ17.27).

26. Драгавцев В.А., Цильке Р.А., Рейтер Б.Г., Воробьев В.А., Дубровская А.Г., Коробейников Н.И., Новохатин В.В., Максименко В.П., Бабакишиев А.Г., Илющенко В.Г., Калашник Н.А., Зуйков Ю.П., Федотов А.М. Генетика признаков продуктивности яровых пшениц в Западной Сибири /Под ред. Д.К. Беляева. Новосибирск, 1984.

27. Глазко В.И., Глазко Г.В. Толковый словарь терминов по общей и молекулярной биологии, общей и прикладной генетике, селекции, ДНК-технологии и биоинформатике. Т. 2. М., 2008: 308.

28. Драгавцев В.А., Литун П.П., Шкель Н.М., Нечипоренко Н.Н. Модель эколого-генетического контроля количественных признаков растений. Доклады АH CCCP, 1984, 274(3): 720-723.

29. Драгавцев В.А. Уроки эволюции генетики растений. Биосфера, 2012, 4(3): 251-262.

30. Дьяков А.Б., Драгавцев В.А. Разнонаправленность сдвигов количественного признака индивидуального организма под влиянием генетических и средовых причин в двумерных системах признаковых координат. В кн.: Эколого-генетический скрининг генофонда и методы конструирования сортов сельскохозяйственных растений по урожайности, устойчивости и качеству. СПб, 1998: 23-47.

31. Кочерина Н.В., Драгавцев В.А. Введение в теорию эколого-генетической организации полигенных признаков растений и теорию селекционных индексов. СПб, 2008.

32. Börner A., Schumann E., Fürste A., Cöster H., Leithold B., Röder M., Weber W. Mapping of quantitative trait loci determining agronomic important characters in hexaploid wheat (Triticum aestivum L.). Theor. Appl. Genet., 2002, 105(6-7): 921-936 (doi: 10.1007/s00122-002-0994-1).

33. Драгавцев В.А., Драгавцева И.А., Ефимова И.Л., Моренец А.С., Савин И.Ю. Управление взаимодействием «генотип-среда» - важнейший рычаг повышения урожаев сельскохозяйственных растений. Труды Кубанского ГАУ, 2016, 2(59): 105-121.

34. Ushiyama T., Nakamura K., Anas A., Yoshida T. Pedigree analysis of early maturing wheat cultivars in Japan for breeding cultivars with higher performance. Plant Production Science, 2009, 12(1): 80-87 (doi: 10.1626/pps. 12.80).

35. Witcombe J.R., Virk D.S. Methodologies for generating variability. Part 2: selection of parents and crossing strategies. In: Plant breeding and farmer participation /S. Ceccarelli, E.P. Guinarres, E. Weltizienm (eds.). Rome, 2009: 129-138.

36. Новохатин В.В. Эффективность различных методов отбора в селекции растений. Достижения науки и техники АПК, 2016, 3: 42-45.

37. Воронин А.Н., Стельмах А.Ф. Генетические эффекты локусов Vrn 1-3 на скорость колошения мягких пшениц. Научно-технический бюллетень ВСГИ, 1985, 3: 25-30.

38. Стельмах А.Ф. Программа селекции пшеницы на скороспелость. Вестник сельскохозяйственной науки, 1987, 6: 47-53.

39. Писарев В.Е. Селекция зерновых культур. М., 1964.

40. Ведров Н.Г. Яровая пшеница в Восточной Сибири. Красноярск, 1998.

41. Jiang Z., Zhang B., Teng W., Han Y., Zhao X., Sun D., Zhang Z., Li W. Impact of epistasis and QTL $\times$ environmental interaction on the oil filling rate of soybean seed at different stages. Euphytica, 2011, 177(3): 431-442 (doi: 10.1007/s10681-010-0290-0).

42. Жученко А.А. Экологическая генетика культурных растений: адаптация, рекомбиногенез, агробиоценоз. Кишинев, 1980.

43. Гилл К.С. Карликовые пшеницы. М., 1984.

44. Кумаков В.А. Соотношение продуктивности и засухоустойчивости генотипов пшеницы. 
Тез. докл. IV Свезда общества физиологов растений России. Международная конференция «Физиология растений - наука 3-го тысячелетия» (Москва, 4-9 октября 1999 года). М., 1999, т. 1: 400 .

45. Жученко А.А. Адаптивный потенциал культурных растений (экологические основы). Кишинев, 1988.

46. Guo R., Wu Q., Liu Y. Single-plant similarity-difference selection in wheat breeding. Advance Journal of Food Science and Technology, 2013, 5(11): 1413-1417 (doi: 10.19026/ajfst.5.3358).

47. Драгавцев В.А., Драгавцева И.А., Ефимова И.Л., Кузнецова А.П., Моренец А.С. К экспериментальному подтверждению гипотезы об эколого-генетической природе феномена «взаимодействие генотип-среда» у древесных растений. Сельскохозяйственная биология, 2018, 53(1): 151-156 (doi: 10.15389/agrobiology.2018.1.151rus).

48. Singh S., Dhindsa G.S., Sharma A., Singh P. Combining ability for grain yield and its components in barley (Hordeum vulgare L.). Crop Improvement, 2007, 34: 128-132.

49. Новохатин В.В., Шеломенцева Т.В. Рост урожайности яровой мягкой пшеницы в Северном Зауралье. Вестник Российской академии сельскохозяйственных наук, 2014, 4: 14-17.

50. Li W.-Q., Zhang Z.-B., Li J.-J. Plant epicuticular wax and drought resistance as well as its molecular biology. Zhi wu sheng li yu fen zi sheng wu xue xue bao = Journal of plant physiology and molecular biology, 2006, 32(5): 505-512 (Article in Chinese).

51. Сюков В.В., Захаров В.Г., Менибаев А.И. Экологическая селекция растений: типы и практика. Вавиловский журнал генетики и селекции, 2017, 21(5): 534-536 (doi: 10.18699/VJ17.290).

52. Borlaug N.E. Wheat breeding and its impact on world food supply. Proc. 3rd Int. Wheat Symp. Canberra-Australia. Canberra, 1968: 1-36.

53. Rajaram S., Borlaug N.E., van Ginkel M. CIMMIT international wheat breeding. In: $F A O$ Plant Production and Protection Series. No. 30. Bread wheat - improvement and production /B.C. Curtis, S. Rajaram, H. Gymez Macpherson (eds.). FAO, Rome, 2002: 103-117.

54. Srinivasan C.S., Thirtle C., Palladino P. Winter wheat in England and Walles, 1923-1995: what do indicates of genetic diversity reveal? Plant Genetic Resources: Characterization and Utilization, 2003; 1(1): 43-57 (doi: 10.1079/PGR20031).

55. Жученко А.А., Король А.Б. Рекомбинация в эволюции и селекции. М., 1985.

56. Fujimura S., Shi P., Iwama K., Zhang X., Gopal J., Jitsuyama Y. Comparison of growth and grain yield of spring wheat in Lhasa, the Tibetan Plateau, with those in Sapporo, Japan. Plant Prod. Sci., 2009, 12(1): 116-123 (doi: 10.1626/pps.12.116).

57. Malik A.H., Prieto-Linde M.L., Kuktaite R., Andersson A., Johansson E. Individual and interactive effects of genetic background and environmental conditions on amount and size distribution of polymeric proteins in wheat grain. Czech J. Genet. Plant Breeding, 2011, 47(spec. Iss.): S186-S189 (doi: 10.17221/3278-CJGPB).

58. Haberle J., Holzapfel J., Hartl L. Die Genetik der Fusariumresistens in ropaischem Winterweizen. In: Abwehrstrategien gegen biotische Schaderreger, Zuchtung Hackfruchten und Sonderkulturen. Irdning, 2009: 5-8.

59. Kosova K., Chrpova J., Sip V. Cereal resistance to Fusarium head blight and possibilities of its improvement through breeding. Czech J. Genet. Plant Breeding, 2009, 45(3): 87-105 (doi: 10.17221/63/2009-CJGPB).

60. El-Hendawy S.E., Ruan Y., Hu Y., Schmidhalter U. A comparison of screen criteria for salt tolerance in wheat under field and controlled environmental conditions. Journal of Agronomy \& Crop Science, 2009, 195(5): 356-367 (doi: 10.1111/j.1439-037X.2009.00372).

61. Новохатин В.В. Обоснование генетического потенциала у интенсивных сортов мягкой пшеницы (Triticum aestivum L.). Сельскохозяйственная биология, 2016, 51(5): 627-635 (doi: 10.15389/agrobiology.2016.5.627rus).

62. Новохатин В.В. Модель сорта яровой пшеницы для Северного Зауралья. Мат. науч.практ. конф. «Сельскохозяйственная наука - развитию АПК Тюменской области» (15-17 февраля 2000 года, Тюмень). Тюмень, 2000: 50-56.

63. Мальчиков П.Н., Мясникова М.Г. Возможности создания сортов яровой твердой пшеницы (Triticum durum Desf.) с широкой изменчивостью параметров вегетационного периода. Вавиловский журнал генетики и селекции, 2015, 19(2): 176-184.

${ }^{1}$ НИИ сельского хозяйства Северного Зауралья - филиал ФГБУН ФИЦ Тюменский научный центр СО РАН, 625501 Россия, Тюменская обл., Тюменский р-н, пос. Московский, ул. Бурлаки, 2, e-mail: natalya_sharapov@bk.ru;

2ФГБНУ Агрофизический научно-исследовательский

\section{институт,}

195220 Россия, г. Санкт-Петербург, Гражданский просп., 14, e-mail: dravial@mail.ru $₫$
Поступила в редакцию 16 ноября 2018 года 


\title{
CREATION OF A SPRING SOFT WHEAT VARIETY GRENADA WITH THE USE OF INNOVATIVE BREEDING TECHNOLOGIES BASED ON THE ORIGINAL THEORY OF ECO-GENETIC ARRANGEMENT OF QUANTITATIVE TRAITS
}

\author{
V.V. Novokhatin ${ }^{1}$, V.A. Dragavtsev ${ }^{2}$, T.A. Leonova1, T.B. Shelomentseva ${ }^{1}$
}

\author{
${ }^{1}$ Research Institute of Agriculture for Northern Zayral'e - Branch of Tyumen Scientific Center, SB RAS, 2, ul. \\ Burlaki, pos. Moskovskii, Tyumen Region, Tyumen Province, 625501 Russia, e-mail natalya_sharapov@bk.ru; \\ ${ }^{2}$ Agrophysical Research Institute, 14, Grazhdanskii prosp., St. Petersburg, 195220 Russia, e-mail dravial@mail.ru ( $\square$ \\ corresponding author) \\ ORCID: \\ Novokhatin V.V. orcid.org/0000-0002-2191-0420 \\ Dragavtsev V.A. orcid.org/0000-0002-0934-020X \\ Leonova T.A. orcid.org/ 0000-0003-2618-9043 \\ The authors declare no conflict of interests \\ Acknowledgements: \\ The work was performed according to the State task (priority area X.10.4, program X.10.4.150, projects X.10.4.150) \\ Received November 16, 2018 \\ doi: 10.15389/agrobiology.2019.5.905eng
}

Today, there is an excessive belief in the promise of molecular approaches to the problem of increasing yields, although so far there is not a single variety created by purely molecular methods. In addition, representatives of the new science, the epigenetics, rightly argue that in nature there are no specific genes for productivity and yield that could be molecularly marked or subjected to genomic editing. This article is the first to describe creation of a wheat variety Grenada using innovative breeding technologies emerged from the priority Russian Theory of Eco-Genetic Organization of Quantitative Traits (TEGOQT) which derived from the results of the Interdisciplinary DIAS Program (genetics of spring wheat productivity in Western Siberia) (1973-1984). The essence of these technologies are 1) a special selection of parental pairs on the basis of a deep analysis of the longest pedigrees of the old breeds of parents taken in crosses, 2) priority phenotyping of the group of the most productive varieties of the collection nursery for seven genetic-physiological systems (GPS) which positively or negatively contribute to the harvest, 3) selection of genotypes that have at least one GPS with the maximum plus contribution to the crop, 4) crossing of these genotypes to combine the plus contributions of all seven GPS in the future variety (with several saturations with the genome of one of the parents with the most valuable properties), 6) selection of elite plants after a number of stabilizing reproduction of the hybrid population under the conditions of typical dynamics of the environment lim-factors (in typical years for the breeding zone). Applying these technologies, we obtained a hybrid combination $\left[F_{1}\right.$ (Kazakhstanskaya rannespelaya $\times$ Tulunskaya 12) with five subsequent saturations with Tulunskaya 12 genome], from which the variety Grenada derived. Both parents of the maternal form Kazakhstanskaya rannespelaya, the Novosibirskaya $67 \times$ Omskaya 9, having wide general adaptability, showed a much lower changes in GPS contribution to productivity as a response to changing environment and good combining ability. The Kazakhstanskaya rannespelaya variety created on their basis combines the best traits of the parents. As to the paternal and saturating form Tulunskaya 12, the improvement in quantitative traits is discrete-accumulative due to the genetic diversity of the East Siberian genotypes. The selection of elite plants under typical agroclimatic conditions resulted in higher yielding genotypes with a pronounced plasticity. A comprehensive assessment of the biotypes from this population in $\mathrm{F}_{5}$ according to seven GPS, positively contributing to productivity, showed their synergetic effect. This was well manifested in the early ripening line Lutescens 506-11 from which the Grenada variety derived. This variety successfully combines high productivity (26-39\% higher compared to the standard) with the resistance to lodging, drought, pre-harvest germination and the grain quality of valuable and strong varieties. A distinctive feature of the variety is the horizontal resistance to Septoria diseases, a dusty smut, powdery mildew, a red-breasted leech, and intra-stem pests. Grenada variety is much lower affected by rust fungi compared to the standard. From one hectare of arable land the Grenada variety gives $628 \mathrm{~kg}$ of protein (+119 $\mathrm{kg}$ to the standard variety). In 2019, the variety Grenada is zoned by State Commission on Variety Testing of the Ministry of Agriculture of the Russian Federation for the 9th (Ural) crop region including Bashkiria (about 1 million hectares), Chelyabinsk (1 million hectares), Orenburg (4 million hectares), Kurgan ( 1 million hectares), and Tyumen (500 thousand hectares) regions. When Grenada occupies these areas (about 7 million hectares), an increase in grain yield will provide an annual economic effect of about 30 million rubles.

Keywords: Triticum aestivum L., soft wheat, breeding, variety, population, selection, biotype, geno-physiological system, grain, immunity. 